Research article

\title{
CLASSICAL SWINE FEVER: ACTIVE IMMUNISATION OF PIGLETS WITH SUBUNIT (E2) VACCINE IN THE PRESENCE OF DIFFERENT LEVELS OF COLOSTRAL IMMUNITY (CHINA STRAIN)
}

\author{
PRODANOV-RADULOVIĆ Jasna ${ }^{1 *}$, DOŠEN Radoslav ${ }^{1}$, POLAČEK Vladimir ${ }^{1}$, \\ PETROVIĆ Tamaš ${ }^{1}$, STOJANOV Igor ${ }^{1}$, RATAJAC Radomir ${ }^{1}$, VALČIĆ Miroslav ${ }^{2}$
}

${ }^{1}$ Scientific Veterinary Institute „Novi Sad“, Novi Sad, Serbia; ${ }^{2}$ Department of Infectious Diseases of Animals and Bees, Faculty of Veterinary Medicine, Belgrade, Serbia

The aim of this study was to investigate the efficacy of the subunit vaccine against virulent CSF infection in piglets deriving from sows vaccinated with China strain. The experimental research included 34 piglets aged 45 days (13 naïve and 21 piglets originating from sows immunized with China strain CSFV). Three experimental groups consisting of seven animals each were formed based on serological examination of piglets aged 40 days. At the age of 45 days, the piglets were vaccinated with a subunit vaccine. After revaccination, the piglets were challenged with a virulent CSFV strain. With the aim of controlling virus shedding, two susceptible piglets were introduced into each group. After challenge, clinical monitoring of animals was performed, and blood samples were obtained to detect viremia and the presence of antibodies against CSF. The control of CSFV shedding by vaccinated, artificially infected piglets was performed by RT-PCR analysis of oropharyngeal and rectal swabs. After death or sacrifice of the animals, autopsy was performed along with the gross pathological examination and tissue sampling with the purpose of determining the presence and distribution of CSFV (ELISA and RT-PCR). Application of the subunit vaccine in piglets originating from sows vaccinated with China-strain resulted in a good active immune response. Following challenge virus shedding was confirmed, but without contact infection in susceptible animals in cohabitation. The results indicate that the subunit vaccine may have a potential application in the control of CSF in enzootic regions.

Key words: classical swine fever, colostral immunity, subunit E2 vaccines

\section{INTRODUCTION}

Classical swine fever (CSF) is a highly contagious viral disease of domestic pigs and wild boar [1], which causes major losses in stock farming due to high mortality rates, compulsory pig slaughter policies and trade bans of live pigs and pig products [2,3]. The etiological agent of CSF is the Classical Swine Fever Virus (CSFV), which is an enveloped RNA virus belonging to the genus Pestivirus of the family Flaviviridae [4]. Two

Corresponding author: e-mail: jasna.prodanov@gmail.com 
main strategies to control CSF epidemics are systematic prophylactic vaccination and a non-vaccination stamping-out policy [5,6]. In the European Union (EU), prophylactic vaccination is banned since 1990 , but legal provision is laid for emergency vaccination under certain circumstances [2,7]. In countries, in which CSF is endemic, prevention and control depend primarily on vaccination programs, using modified live-virus vaccines (MLV) [3,5]. In Serbia the disease is endemic and control of CSF has been done by China (C)-strain mass vaccination $[8,9,10]$. According to National Directive on CSF, compulsory vaccination is requested for all piglets 45-60 days of age, gilts and sows at least 15 days before each insemination, and boars every 6 months $[8,11]$. The C-strain vaccine is considered safe and effective in the induction of protective immunity against CSFV [2,3]. However, extensive vaccination with MLV against CSF creates a problem, because vaccination of young animals frequently fails to establish solid immunity due to the interference of colostral antibodies upon vaccination $[8,12]$.

Despite of vaccination policy, the last outbreak of CSFV in Serbia was reported in 2010 [11]. Compared to the huge costs and in some cases inadequacy of stamping out, MLV are inexpensive $[3,6]$. However, pigs vaccinated with $\mathrm{C}$-strain cannot be serologically differentiated from those infected with CSFV field strains, thus it may reside undetected in parts of the population $[2,13]$. The inability of a country to prove the CSF-free status by serosurveillance, leads to restrictions in the pig export. To overcome this problem, effective and safe subunit E2 marker vaccines with accompanying diagnostic tests are developed [6,7]. Two subunit vaccines based on baculovirus expression of the CSFV E2 glycoprotein have been registered [13,14]. The glycoprotein E2 exposed on the outer surface of the virus is the most immunogenic among all CSFV proteins, inducing production of neutralizing antibodies and protection against lethal challenge $[2,4]$. Subunit vaccines can be used for prophylactic vaccination; however they have a restricted use due to repeated administration needed to induce protection $[13,15]$. Until now, they have not been successfully promoted in CSF endemic areas [4,6].

By conducting the program of CSF eradication, Serbia approaches the moment when vaccination with $C$-strain against $\mathrm{CSF}$ will be ceased $[11,16]$. The next phase of the CSF eradication program, might include prophylactic vaccination with the subunit vaccine at the regional level, i.e. after compartmentalization of the country upon CSF risk assessment. On the field, there will be scenarios with previous vaccinations using C-strain vaccine; this may lead to use subunit vaccines in piglets that possess maternally derived antibodies (MDA) against CSF. Although high levels of MDA may protect piglets against CSF, they also interfere with the active immunization $[3,8]$. The objective of this study was to evaluate the efficacy of the subunit vaccine for the protection against virulent CSFV challenge in weaned piglets, which originate from sows repeatedly vaccinated with C-strain of CSFV. The aim of the research was also to investigate whether the active immunity in vaccinated piglets prevents the development of the disease, shedding and spread of the CSFV. 


\section{MATERIALS AND METHODS}

\section{Animals, vaccine and virus}

To determine the presence of colostral antibodies in the serum of weaned piglets, blood sampling was performed in 100 clinically healthy, weaned piglets (crossbreeds of Landrace and Large White) aged 40 days from the selected swine farm. Based on serological examination (ELISA test), three experimental groups consisting of seven animals each were formed: Positive Group (A) (confirmed presence of colostral antibodies), Negative Group (B) (presence of colostral antibodies not confirmed) and Suspect Group (C) (animals in which the antibodies were detected at the detection limit level). The experiment was carried out on 34 clinically healthy, conventional weaner piglets, divided into 4 groups (A, B, C, D). The experimental groups A, B, C consisted of 7 piglets of 45 days of age originating from sows that were vaccinated with C-strain of CSFV, according to the National Directive on CSF. The experimental group D consisted of 13 susceptible (naïve) pigs, 45 days old, divided in two subgroups: D-control (7 piglets) and D-contact (6 piglets). After selecting the piglets ear tagging was carried out. All experimental animals were examined for the absence of bovine viral diarrhea virus (BVDV-1 and BVDV-2) antibodies and CSFV antigen at their arrival. The vaccine used was a subunit E2 marker vaccine (Porcilis $₫$ Pesti, Intervet International B.V.) consisting of the E2 glycoprotein of the CSFV, strain Alfort ${ }_{187} /$ Tübingen. The glycoprotein was produced by means of a baculovirus expressing the protein in insect cells. All pigs were vaccinated and revaccinated intra-muscularly $(\mathrm{i} / \mathrm{m})$ with a single vaccine dose of $2 \mathrm{~mL}$, according to manufacturer's instruction. For the challenge a virulent CSFV (strain Baker) was used. The challenge virus was verified to be free from BVDV by means of RT-PCR. The pigs were challenged with a $1 \mathrm{~mL}$ dose by $\mathrm{i} / \mathrm{m}$ route. The titer was $10^{3} \mathrm{TCID}_{50} / \mathrm{mL}$.

\section{Experimental design}

The experiment was divided into four subsequent stages: acclimatization, vaccinationrevaccination, challenge and post-challenge period. Upon arrival, piglets were allocated systematically to pens within 4 separate compartments. After an acclimatization period, when the piglets originating from vaccinated sows were 45 days old, the three groups of piglets (A, B, C) were vaccinated and revaccinated four weeks later (at the age of 73 days) with a subunit vaccine. Fourteen days after revaccination with the subunit vaccine, at the age of 87 days, the piglets were challenged with the virulent CSFV strain (Baker strain). One day following artificial infection, with the aim of controlling virus shedding and to investigate the possibility of contact infection, two susceptible (naïve) piglets from the subgroup D-contact were introduced into each of the aforementioned A, B, C groups. The D-control subgroup consisted of 7 susceptible (naïve) piglets, where experimental infection was performed on the same day, according to the same model $\left(\mathrm{i} / \mathrm{m}, 1 \mathrm{~mL}\right.$, titer $\left.10^{3} \mathrm{TCID}_{50} / \mathrm{mL}\right)$. After artificial infection, each time 
before sample collection, all pigs were clinically examined. At clinical examination, the following symptoms were recorded: liveliness (apathy, lethargy), conjunctivitis, constipation-diarrhoea, coughing, ataxia, convulsions, posterior paresis, erythema and haemorrhages of the skin. Rectal temperature and mortality were recorded daily. Fever was defined as body temperature higher than $40^{\circ} \mathrm{C}[13,15,16]$.

The animals were housed in the Experimental Diagnostic Centre of the Scientific Veterinary Institute "Novi Sad", Novi Sad, Serbia. All groups of piglets were housed under identical conditions in four separate compartments. Each compartment consisted of a well isolated area of $35 \mathrm{~m}^{2}$, with independent ventilation, assigned for experimental work with animals. Technical design and biosafety measures entirely prevented the possibility of mechanic transmission of the virus from one compartment into the other. All materials used for blood sampling, rectal temperature monitoring, cleansing of the compartments and pens, and feeding of pigs were provided per compartment and were stored at the compartment. The study has been conducted in full accordance with the Animal Welfare Act (Serbian Official Gazette, No 41/2009).

\section{Sample collection - blood, sera and tissue samples}

From the day when 28 piglets from A, B, C groups and D-control subgroup were experimentally infected, blood samples were obtained from the jugular vein of each individual piglet according to the following sampling scheme: $0,2,4,6,8,10$, $12,14,16,18,20,22,24,26,28$ days post infection (dpi) to detect the presence of antibodies against CSF, viremia and viral RNA (ELISA test and RT-PCR). The control of CSFV shedding by vaccinated, artificially infected piglets was performed by RTPCR analysis of oropharyngeal and rectal swabs with the following sampling scheme: 0, 2, 4, 6, 8 and 10 dpi. Necropsy was performed on all animals immediately after death. Euthanasia of surviving piglets was performed on $30 \mathrm{dpi}$, using an intravenous injection of $0.5 \mathrm{ml} / \mathrm{kg}$ T61 (embutramide $200 \mathrm{mg} / \mathrm{ml}$; mebezonium iodide $50 \mathrm{mg} / \mathrm{ml}$; tetracaine hydrochloride $5 \mathrm{mg} / \mathrm{ml}$, Intervet International) and proper premedication with $80 \mathrm{mg} / \mathrm{kg}$ azaperone (Stresnil, Janssen). Tissue samples (tonsils, spleen, kidney, terminal part of ileum and mandibular lymph nodes) were collected from every pig in order to examine the presence and distribution of CSFV (antigen ELISA test and RT-PCR).

\section{Sample analysis - serum antibody and CSF antigen detection}

For CSF serum antibody detection the commercial indirect immunoenzyme test (ELISA) kit (Classical Swine Fever Virus Antibody Test Kit, HerdChek CSFVAb, IDEXX Laboratories, USA) was used according to manufacturer's instructions. To establish the presence of BVDV antibodies virus-neutralization (VN) test was used. The test was carried out using 100 TCID $_{50} / 0.1 \mathrm{ml} \mathrm{NADL} \mathrm{(BVDV-1)} \mathrm{and} 178003$ (BVDV-2) strains of BVDV, on BT cell culture (previously proved as BVDV free). For the detection of CSF antigen in EDTA blood and tissue samples the commercial 
ELISA test kit (Classical Swine Fever Virus Antigen Test Kit, HerdChek CSFV Ag, IDEXX Laboratories, USA) was used according to manufacturer's instructions. Detection of glycoprotein $\mathrm{E}^{\mathrm{rns}}$ serum antibody was performed using the commercial marker immunoenzyme test (D-ELISA) kit (Classical Swine Fever Marker Antibody test Kit, Chekit CSF Marker, IDEXX Laboratories, USA) according to manufacturer's instructions.

\section{Detection of viral RNA in the blood and tissues samples}

Reverse transcriptase-polymerase chain reaction (RT-PCR) test was applied to detect genomic RNA of CSFV in unclotted blood and tissue samples. This test was used for direct detection of CSFV in the blood and tissues samples, which gave a positive or doubtful result on CSFV antigen in ELISA.

Total RNA was extracted directly from $250 \mu \mathrm{l}$ of $10 \%$ suspensions of tissues samples in PBS and blood samples using TRIzol ${ }^{\circledR}$ reagent (Invitrogen "Life Technologies") according to manufacturer's recommendations. Briefly, $750 \mu$ l of TRIzol ${ }^{\circledR}$ reagent was mixed with $250 \mu \mathrm{l}$ of sample. After $10 \mathrm{~min} 200 \mu \mathrm{l}$ of chloroform was added, mixed and the suspension was centrifuged for $15 \mathrm{~min}$ at $14,000 \mathrm{~g}$ at $4^{\circ} \mathrm{C}$. The RNA containing aqueous phase was removed and precipitated with $500 \mu \mathrm{l}$ of isopropanol, maintained at room temperature for $10 \mathrm{~min}$, and centrifuged for $10 \mathrm{~min}$ at 14,000 g. The RNA pellet was washed with $500 \mu \mathrm{l}$ of $75 \%$ ethanol, centrifuged for $5 \mathrm{~min}$ at 12,000 g, dried, and resuspended in $40 \mu \mathrm{l}$ of diethyl pyrocarbonate (DEPC) treated water and stored at $-70^{\circ} \mathrm{C}$ until examination or was immediately included in RT-PCR. The "one-step RT-PCR" assay was performed by a commercial "Access RT-PCR system" (Promega Corporation, UK). The E2 region of the CSFV genome was amplified with primers described by Katz et al. [17] (gp55-U: 5'-ATA TAT GCT CAA GGG CGA GT-3' (sense, position in genome of the Alfort strain is 3378-3397) and gp55-L:5'-ACA GCA GTA GTA TCC ATT TCT TTA-3' (antisense, position in genome of the Alfort strain is $3685-3662)$. In the reactions $6 \mu \mathrm{l}$ of RNA sample was added to $44 \mu \mathrm{l}$ reaction mixtures containing AMV $/ T f 1 \times$ reaction buffer, dNTP mix $(10 \mathrm{mM}), 25$ pmol of sense and antisense primer, $1 \mathrm{mM}$ of $\mathrm{MgSO}_{4}, 5 \mathrm{U}$ of AMV RT and $5 \mathrm{U}$ of $\mathrm{T} f \mathrm{DNA}$ polymerase. The RT-PCR cycling conditions were as follows, $45 \mathrm{~min}$ at $48^{\circ} \mathrm{C}$ for RT, $94^{\circ} \mathrm{C}$ for 2 min for AMV RT inactivation and RNA/cDNA/ primer denaturation, 40 cycles of $30 \mathrm{~s}$ at $94^{\circ} \mathrm{C}, 1 \mathrm{~min}$ at $60^{\circ} \mathrm{C}$ and $2 \mathrm{~min}$ at $68^{\circ} \mathrm{C}$, and a final extension step at $68^{\circ} \mathrm{C}$ for $7 \mathrm{~min}$. Amplified products were visualized on $1.5 \%$ agarose gel stained with ethidium bromide.

\section{RESULTS}

\section{Antibody detection}

Control of colostral antibodies in the blood sera from piglets at 40 days of age, originating from sows immunized with C-strain of CSFV, revealed their presence 
Table 1. Results of experimental blood sera examined by ELISA test on presence of CSFV antibodies

\begin{tabular}{|c|c|c|c|c|c|c|c|c|c|c|c|c|c|c|c|c|c|}
\hline \multirow{2}{*}{$\begin{array}{l}\text { Experimental } \\
\text { group }\end{array}$} & \multicolumn{17}{|c|}{ Days post-infection (dpi) } \\
\hline & No. & * & 0 & 2 & 4 & 6 & 8 & 10 & 12 & 14 & 16 & 18 & 20 & 22 & 24 & 26 & 28 \\
\hline \multirow{9}{*}{$\begin{array}{l}\text { Group A } \\
\text { (positive) }\end{array}$} & 1 & + & + & + & + & + & + & + & + & + & + & + & + & + & + & + & + \\
\hline & 2 & + & + & + & + & + & + & + & + & + & + & + & + & + & + & + & + \\
\hline & 3 & + & + & + & + & + & + & + & + & + & + & + & + & + & + & + & + \\
\hline & 4 & + & + & + & + & + & + & + & + & + & + & + & + & + & + & + & + \\
\hline & 5 & + & + & + & + & + & + & + & + & + & + & + & + & + & + & + & + \\
\hline & 6 & + & + & + & + & $\dagger$ & & & & & & & & & & & \\
\hline & 7 & + & + & + & + & + & + & + & + & + & + & + & + & + & + & + & + \\
\hline & S1 & - & - & - & - & - & - & - & - & - & - & - & - & - & - & - & - \\
\hline & S2 & - & - & - & - & - & - & - & - & - & - & - & - & - & - & - & - \\
\hline \multirow{9}{*}{$\begin{array}{l}\text { Group B } \\
\text { (negative) }\end{array}$} & 8 & - & + & + & + & + & + & + & + & + & + & + & + & + & + & + & + \\
\hline & 9 & - & + & + & + & + & + & + & + & + & + & + & + & + & + & + & + \\
\hline & 10 & - & + & + & + & + & + & + & + & + & + & + & + & + & + & + & + \\
\hline & 11 & - & + & + & + & + & + & + & + & + & + & + & + & + & + & + & + \\
\hline & 12 & - & + & + & + & + & + & + & + & + & + & + & + & + & + & + & + \\
\hline & 13 & - & + & + & + & + & + & + & + & + & + & + & + & + & + & + & + \\
\hline & 14 & - & + & + & + & + & + & + & + & + & + & + & + & + & + & + & + \\
\hline & S3 & - & - & - & - & - & - & - & - & - & - & - & - & - & - & - & - \\
\hline & S4 & - & - & - & - & - & - & - & - & - & - & - & - & - & - & - & - \\
\hline \multirow{9}{*}{$\begin{array}{l}\text { Group C } \\
\text { (suspect) }\end{array}$} & 15 & \pm & + & + & + & + & + & + & + & + & + & + & $t$ & & & & . \\
\hline & 16 & \pm & + & + & + & + & + & + & + & + & + & + & + & + & + & + & + \\
\hline & 17 & \pm & + & + & + & + & + & + & + & + & + & + & + & + & + & + & + \\
\hline & 18 & \pm & + & + & + & + & + & + & + & + & + & + & + & + & + & + & + \\
\hline & 19 & \pm & + & + & + & + & + & + & + & + & + & + & + & + & + & + & + \\
\hline & 20 & \pm & + & + & + & + & + & + & + & + & + & + & + & + & + & + & + \\
\hline & 21 & \pm & + & + & + & + & + & + & + & + & + & + & + & + & + & + & + \\
\hline & S5 & - & - & - & - & - & - & - & - & - & - & - & - & - & - & - & - \\
\hline & S6 & - & - & - & - & - & - & - & - & - & - & - & - & - & - & - & - \\
\hline \multirow{7}{*}{$\begin{array}{l}\text { Subgroup } \\
\text { D-control }\end{array}$} & K1 & - & - & - & - & - & - & - & - & $\dagger$ & & & & & & & \\
\hline & K2 & - & - & - & - & - & - & - & - & $\dagger$ & & & & & & & \\
\hline & $\mathrm{K} 3$ & - & - & - & - & - & - & $\dagger$ & & & & & & & & & \\
\hline & K4 & - & - & - & - & - & - & $\dagger$ & & & & & & & & & \\
\hline & K5 & - & - & - & - & - & - & - & $\dagger$ & & & & & & & & \\
\hline & K6 & - & - & - & - & - & - & - & $\dagger$ & & & & & & & & \\
\hline & K7 & - & - & - & - & - & - & - & - & $\dagger$ & & & & & & & \\
\hline
\end{tabular}

*- level of colostral antibodies at 40 days of piglets' age; No. - ear-tag number; S1-S6- susceptible piglets; (-) negativ ELISA result; $( \pm)$ suspect (doubtful) ELISA result; $(+)$ positive ELISA result; $(\dagger)$ - death of experimental animal 
in $44 \%$ of investigated piglets, whereas a negative $(35 \%)$ or suspect $(21 \%)$ finding was obtained in more than a half of the animals. In pre-challenge sera samples from vaccinated piglets (A, B, C group), antibodies against CSF were detected in all examined samples (Table 1). During the further course of investigation (2-28 dpi) the presence of antibodies was confirmed in all examined blood sera. The only exception was piglet No. 6 from group A, which was serologically tested only at days 2 and 4 post infection (positive finding) since it died on 6 dpi. Furthermore, piglet No. 15 from group $\mathrm{C}$ died on $20 \mathrm{dpi}$ and its positive serological findings pertain to the period 0-18 dpi. The examination of blood sera of 6 non-vaccinated piglets originating from non-vaccinated sows (D-contact group, No. S1 - S6) did not reveal the presence of CSFV antibodies. The presence of CSFV antibodies was not confirmed in the blood sera of piglets from the D-control group (No. K1 - K6) both at the beginning of the experimental period and after artificial infection. Examination of blood sera of nonvaccinated piglets that were exposed to contact infection (No. S1 - S6) using D-ELISA test did not reveal the presence of $\mathrm{E}^{\mathrm{rns}}$ antibodies against CSFV throughout the entire experimental period (0-28 dpi).

\section{Clinical and gross morphological findings}

Following artificial infection ( $2 \mathrm{dpi}$ ), piglet No. 6 from group A, manifested clinical signs of apathy and inappetence. Afterwards, on $3 \mathrm{dpi}$, fever $\left(41.5^{\circ} \mathrm{C}\right)$ associated with worsening of general health condition and occurrence of nervous symptoms (muscle contractions progressing to convulsions, epileptiform seizures, paddlingleg movements) followed by total exhaustion, decumbency and almost complete unconsciousness were recorded. During 4 and $5 \mathrm{dpi}$, the nervous symptoms associated with fever $\left(41.0^{\circ} \mathrm{C}\right.$ and $40.9^{\circ} \mathrm{C}$ ) intensified resulting in death on day 6 post infection. Clinical signs such as mild inappetence, decumbency and absence of fever were observed in other animals from this group on 3 and $4 \mathrm{dpi}$. In the group B, somewhat poor food intake associated with pronounced apathy and decumbency was observed on days 2-4 post artificial infection. In individual piglets No. 9, 11 and 14 the fever was recorded reaching $40^{\circ} \mathrm{C}$, $40.3^{\circ} \mathrm{C}$ and $40.1^{\circ} \mathrm{C}$, respectively. Afterwards, no clinical manifestations of CSF were recorded in this group until the end of the experimental period. After challenge, fever and decreased interest for food was recorded in piglets No. $15\left(40.6^{\circ} \mathrm{C}\right)$ and No. 18 $\left(40.8^{\circ} \mathrm{C}\right)$ from group C. Until the end of the experimental period, no clinical signs of CSF were observed in this group. The piglet No. 15 was ill from $10 \mathrm{dpi}$ and died on 19 dpi manifesting severe respiratory clinical symptoms (dyspnea, cough and purulent nasal discharge). In non-immune piglets (No. S1 - S6) exposed to contact infection during the experimental period, clinical signs of CSF were not observed. Following CSFV challenge, all animals from the D-control subgroup exhibited distinct clinical signs of CSFV infection starting from 2 and 3 dpi. Clinical symptoms included fever (40.4 - $\left.41^{\circ} \mathrm{C}\right)$, lethargy, conjunctivitis, constipation and diarrhea that started from 4 dpi. The clinical picture was dominated by locomotory disorders with signs of ataxia, posterior paresis and paralysis. All animals in this group died on $13 \mathrm{dpi}$. 
All animals were submitted to a complete necropsy. In succumbed piglets (No. 6, 15) gross pathology examination revealed changes characteristic for CSF (purulent to diphteroid tonsillitis, petechial hemorrhages on epiglottis, kidneys, urinary bladder and rectal mucosa and lymphadenitis). Also, in most of the piglets that survived the experimental infection, and were euthanized on $30 \mathrm{dpi}$, gross pathology examination revealed changes that suspected an infection with CSFV (petechial hemorrhages in the urinary bladder, lymphadenitis). In susceptible piglets (No. S1 - S6) exposed to contact infection, pathological lesions characteristic for CSF were not detected. In the control group, the gross pathology lesions were characteristic for the acute course of CSF, which is in accordance with the results of Prodanov et al. [8] and Polaček et al. [16].

\section{Detection of CSFV antigen and viral RNA in blood samples}

The results related to CSFV antigen (ELISA) and genome detection (RT-PCR technique) in blood samples according to experimental groups, are summarized in Table 2. In blood samples of piglets from all experimental groups viremia was detected by using one of the applied methods. ELISA analysis of blood samples revealed the first suspect finding of viral antigens in groups A, B, C as early as $4 \mathrm{dpi}$ (No. 6, 9, 16 and 18) and 6 dpi (No. 4, 7, 9, 11, 14, 15). During the further course of investigation, suspect and positive findings were recorded on 8, 10 and $16 \mathrm{dpi}$. Analysis of blood samples, which previously proved positive and suspect (using antigen ELISA test) by applying RT-PCR technique revealed the presence of viral RNA on 4 dpi (No. 6, 9, 18), 6 dpi (No. 4, 7, 11, 15), 8 dpi (No. 1, 4), 10 dpi (No. 2, 4, 15, 18, 21) and 16 dpi (No. 4, 21). In the susceptible piglets from D-contact group (No. S1-S6), that were exposed to contact infection, the CSF antigen in the blood (viremia) was not detected. In all inoculated piglets from D-control group, viremia was detected by ELISA as early as $2 \mathrm{dpi}$. During the further course of investigation and until the moment of death, presence of CSFV antigen was confirmed in all blood samples.

\section{Detection of viral RNA in oropharyngeal and rectal swabs}

The control of CSF virus shedding by artificially infected vaccinated piglets was performed by examining samples of oropharyngeal (ORF) and rectal (RE) swabs using RT-PCR at two-day intervals (2-10 dpi). Examination of ORF and RE swabs revealed the presence of viral RNA in all experimental groups (Table 3). Testing of ORF swabs for the presence of viral RNA revealed a positive finding on $4 \mathrm{dpi}$ at the earliest (No. 6, 8, 9, 18), on 6 dpi (No. 4, 9, 15) and on 8 dpi in three piglets (No. 1, 2, 21). Testing of RE swabs for the presence of viral RNA revealed a positive finding on $4 \mathrm{dpi}$ at the earliest (No. 6, 18), on $6 \mathrm{dpi}($ No. 1, 7, 8) and on $8 \mathrm{dpi}$ in three piglets (No. 2, 4, 15). 
Table 2. Detection of CSFV antigen (ELISA test) and detection of viral RNA by RT-PCR technique in blood samples of experimental animals

\begin{tabular}{|c|c|c|c|c|c|c|c|c|c|c|c|c|c|c|c|c|}
\hline \multirow{2}{*}{$\begin{array}{l}\text { Experimantal } \\
\text { Group }\end{array}$} & \multicolumn{16}{|c|}{ Days post-infection (dpi) } \\
\hline & No. & 0 & 2 & 4 & 6 & 8 & 10 & 12 & 14 & 16 & 18 & 20 & 22 & 24 & 26 & 28 \\
\hline \multirow{9}{*}{$\begin{array}{l}\text { Group A } \\
\text { (positive) }\end{array}$} & 1 & - & - & - & - & $\pm \oplus$ & - & - & - & - & - & - & - & - & - & - \\
\hline & 2 & - & - & - & - & - & $\pm \oplus$ & - & - & - & - & - & - & - & - & - \\
\hline & 3 & - & - & - & - & - & - & - & - & - & - & - & - & - & - & - \\
\hline & 4 & - & - & - & $\pm \oplus$ & $+\oplus$ & $+\oplus$ & - & - & $\pm \oplus$ & - & - & - & - & - & - \\
\hline & 5 & - & - & - & - & $\pm \varnothing$ & $\pm \varnothing$ & - & - & - & - & - & - & - & - & - \\
\hline & 6 & - & - & $\pm \oplus$ & $\dagger$ & & & & & & & & & & & \\
\hline & 7 & - & - & - & $\pm \oplus$ & & $\pm \varnothing$ & - & - & - & - & - & - & - & - & - \\
\hline & S1 & - & - & - & - & - & - & - & - & - & - & - & - & - & - & - \\
\hline & S2 & - & - & - & - & - & - & - & - & - & - & - & - & - & - & - \\
\hline \multirow{9}{*}{$\begin{array}{l}\text { Group B } \\
\text { (negative) }\end{array}$} & 8 & - & - & & - & - & - & - & - & - & - & - & - & - & - & - \\
\hline & 9 & - & - & $\pm \oplus$ & $\pm \varnothing$ & - & - & - & - & - & - & - & - & - & - & - \\
\hline & 10 & - & - & - & - & - & - & - & - & - & - & - & - & - & - & - \\
\hline & 11 & - & - & - & $\pm \oplus$ & - & $\pm \varnothing$ & - & - & - & - & - & - & - & - & - \\
\hline & 12 & - & - & - & - & - & $\pm \varnothing$ & - & - & - & - & - & - & - & - & - \\
\hline & 13 & - & - & - & - & - & - & - & - & - & - & - & - & - & - & - \\
\hline & 14 & - & - & - & $\pm \varnothing$ & - & - & - & - & - & - & - & - & - & - & - \\
\hline & S3 & - & - & - & - & - & - & - & - & - & - & - & - & - & - & - \\
\hline & S4 & - & - & - & - & - & - & - & - & - & - & - & - & - & - & - \\
\hline \multirow{11}{*}{$\begin{array}{l}\text { Group C } \\
\text { (suspect) }\end{array}$} & 15 & - & - & - & $\pm \oplus$ & - & $+\oplus$ & - & - & - & - & $\dagger$ & & & & \\
\hline & 16 & - & - & $\pm \varnothing$ & - & - & - & - & - & - & - & - & - & - & - & - \\
\hline & 17 & - & - & - & - & - & $\pm \varnothing$ & - & - & - & - & - & - & - & - & - \\
\hline & 18 & - & - & $\pm \oplus$ & - & - & $+\oplus$ & - & - & - & - & - & - & - & - & - \\
\hline & 19 & - & - & - & - & - & - & - & - & - & - & - & - & - & - & - \\
\hline & 20 & - & - & - & - & - & - & - & - & - & - & - & - & - & - & - \\
\hline & 21 & - & - & - & - & - & $\pm \oplus$ & - & - & $\pm \oplus$ & - & - & - & - & - & - \\
\hline & S6 & - & - & - & - & - & - & - & - & - & - & - & - & - & - & - \\
\hline & S7 & - & - & - & - & - & - & - & - & - & - & - & - & - & - & - \\
\hline & K1 & - & + & + & + & + & + & + & $\dagger$ & & & & & & & \\
\hline & K2 & - & \pm & + & + & + & + & + & $\dagger$ & & & & & & & \\
\hline \multirow{5}{*}{$\begin{array}{l}\text { Subgroup } \\
\text { D-control }\end{array}$} & $\mathrm{K} 3$ & - & + & + & + & + & $\dagger$ & & & & & & & & & \\
\hline & K4 & - & + & + & + & + & $\dagger$ & & & & & & & & & \\
\hline & K5 & - & \pm & + & + & + & + & $\dagger$ & & & & & & & & \\
\hline & K6 & - & \pm & + & + & + & + & $\dagger$ & & & & & & & & \\
\hline & K7 & - & + & + & + & + & + & + & $\dagger$ & & & & & & & \\
\hline
\end{tabular}

No. - ear-tag number; (-) negative ELISA result; $( \pm)$ doubtful ELISA result; $(+)$ positive ELISA result; $(\oplus)$ - positive RT-PCR result; $(\varnothing)$ - negative RT-PCR result; $(\dagger)$ - death of experimental animal 
Table 3. Detection of viral RNA by RT-PCR technique in oropharyngeal and rectal swabs of experimental animals

\begin{tabular}{|c|c|c|c|c|c|c|c|c|c|c|c|}
\hline \multirow{3}{*}{\multicolumn{2}{|c|}{$\begin{array}{l}\text { Experimental } \\
\text { group } \\
\\
\\
\text { No. }\end{array}$}} & \multicolumn{10}{|c|}{ Days post infection (dpi) } \\
\hline & & \multicolumn{2}{|c|}{2} & \multicolumn{2}{|c|}{4} & \multicolumn{2}{|c|}{6} & \multicolumn{2}{|c|}{8} & \multicolumn{2}{|c|}{10} \\
\hline & & ORF & RE & ORF & RE & ORF & $\mathbf{R E}$ & ORF & $\mathbf{R E}$ & ORF & RE \\
\hline \multirow{7}{*}{$\begin{array}{l}\text { Group A } \\
\text { (positive) }\end{array}$} & 1 & - & - & - & - & - & + & + & - & - & - \\
\hline & 2 & - & - & - & - & - & - & + & + & - & - \\
\hline & 3 & - & - & - & - & - & - & - & - & - & - \\
\hline & 4 & - & - & - & - & + & - & - & + & - & - \\
\hline & 5 & - & - & - & - & - & - & - & - & - & - \\
\hline & 6 & - & - & + & + & $\dagger$ & & & & & \\
\hline & 7 & - & - & - & - & - & + & - & - & - & - \\
\hline \multirow{7}{*}{$\begin{array}{l}\text { Group B } \\
\text { (negative) }\end{array}$} & 8 & - & - & + & - & - & + & - & - & - & - \\
\hline & 9 & - & - & + & - & + & - & - & - & - & - \\
\hline & 10 & - & - & - & - & - & - & - & - & - & - \\
\hline & 11 & - & - & - & - & - & - & - & - & - & - \\
\hline & 12 & - & - & - & - & - & - & - & - & - & - \\
\hline & 13 & - & - & - & - & - & - & - & - & - & - \\
\hline & 14 & - & - & - & - & - & - & - & - & - & - \\
\hline \multirow{7}{*}{$\begin{array}{l}\text { Group C } \\
\text { (suspect) }\end{array}$} & 15 & - & - & - & - & + & - & - & + & - & - \\
\hline & 16 & - & - & - & - & - & - & - & - & - & - \\
\hline & 17 & - & - & - & - & - & - & - & - & - & - \\
\hline & 18 & - & - & + & + & - & - & - & - & - & - \\
\hline & 19 & - & - & - & - & - & - & - & - & - & - \\
\hline & 20 & - & - & - & - & - & - & - & - & - & - \\
\hline & 21 & - & - & - & - & - & - & + & - & - & - \\
\hline
\end{tabular}

$(\mathrm{ORF})$ - oropharyngeal swab; (RE) - rectal swab; (+) positive RT-PCR result; (-) negative RT-PCR result

\section{Detection of CSFV in tissue samples}

The results of CSFV antigen and genome detection in tissue samples are summarized in Table 4. Equal numbers of positive findings for the viral antigen (ELISA test) was established in groups A and B. RT-PCR confirmed the presence of viral RNA in all samples with a positive and suspect finding obtained by ELISA. A completely different result was recorded in group C: the presence of CSFV antigen was not established in organ samples only in piglet No. 16. In all the other piglets from this group, a positive finding was established. In all the examined tissue samples derived from the control (D) group, the presence of CSFV antigen was detected by ELISA. 
Table 4. Detection of CSFV in tissue samples of experimentally infected piglets

\begin{tabular}{|c|c|c|c|c|c|c|c|c|c|c|c|}
\hline \multirow{2}{*}{$\begin{array}{l}\text { Experimental } \\
\text { group }\end{array}$} & \multirow{2}{*}{$\frac{\text { No. }}{1}$} & \multicolumn{2}{|c|}{ Tonsils } & \multicolumn{2}{|c|}{ Spleen } & \multicolumn{2}{|c|}{ Kidney } & \multicolumn{2}{|c|}{$\begin{array}{l}\text { Mandibular } \\
\text { lymph nodes }\end{array}$} & \multicolumn{2}{|c|}{ Ileum } \\
\hline & & & & & & & & + & $\oplus$ & & \\
\hline \multirow{8}{*}{$\begin{array}{l}\text { Group A } \\
\text { (positive) }\end{array}$} & 2 & & & & & \pm & $\oplus$ & & & & \\
\hline & 3 & & & & & & & & & & \\
\hline & 4 & & & & & & & & & + & $\oplus$ \\
\hline & 5 & & & & & & & & & & \\
\hline & 6 & & & & & & & & & & \\
\hline & 7 & & & & & & & & & + & $\oplus$ \\
\hline & S1 & & & & & & & & & & \\
\hline & S2 & & & & & & & & & & \\
\hline \multirow{9}{*}{$\begin{array}{l}\text { Group B } \\
\text { (negative) }\end{array}$} & 8 & & & \pm & $\oplus$ & & & & & \pm & $\oplus$ \\
\hline & 9 & & & + & $\oplus$ & & & & & & \\
\hline & 10 & & & & & & & & & & \\
\hline & 11 & & & & & & & & & & \\
\hline & 12 & & & + & $\oplus$ & & & & & & \\
\hline & 13 & & & & & & & & & & \\
\hline & 14 & & & & & & & & & & \\
\hline & S3 & & & & & & & & & & \\
\hline & S4 & & & & & & & & & & \\
\hline \multirow{9}{*}{$\begin{array}{l}\text { Group C } \\
\text { (suspect) }\end{array}$} & 15 & \pm & $\oplus$ & \pm & $\oplus$ & & & \pm & $\oplus$ & & \\
\hline & 16 & & & & & & & & & & \\
\hline & 17 & \pm & $\oplus$ & & & & & & & & \\
\hline & 18 & + & $\oplus$ & & & & & + & $\oplus$ & & \\
\hline & 19 & & & \pm & $\oplus$ & \pm & $\oplus$ & & & & \\
\hline & 20 & \pm & $\oplus$ & \pm & $\oplus$ & & & & & \pm & $\oplus$ \\
\hline & 21 & + & $\oplus$ & & & & & + & $\oplus$ & & \\
\hline & S5 & & & & & & & & & & \\
\hline & S6 & & & & & & & & & & \\
\hline
\end{tabular}

No.- ear-tag number; $(+)$ positive ELISA result; (-) negative ELISA result; $( \pm)$ doubtful ELISA result; $(\oplus)$ - positive RT-PCR result

\section{DISCUSSION}

Control of colostral antibodies in the blood sera from piglets originating from sows immunized with C-strain of CSF virus, revealed their presence in $44 \%$ of investigated piglets, whereas a negative or suspect finding was obtained in more than a half $(56 \%)$ 
of the animals (ELISA test). The obtained serological results indicated a significant difference between piglets MDAs. Prodanov et al. [8] suggested that not all piglets born to vaccinated sows have MDA at a detectable level and this emerges the question of the efficiency of passive immunity. Since MDA are the most common factor that influences the efficacy of vaccination with MLV against CSFV in the field, vaccination with subunit E2 vaccine of MDA positive pigs has been compared with the vaccination of MDA negative pigs and no differences have been observed [3].

The prevalence of MDA at the vaccination stage significantly impaired the efficacy of C-strain vaccine in the field $[4,8]$. This effect is probably caused by neutralization of the vaccine virus by the MDAs, which may result in different responses to the vaccine $[12,15]$. However, the prevalence of MDAs in piglets can vary greatly from herd to herd because of the different immune status of sows, which results in difficulties to set up a proper vaccination program for piglets $[8,12]$. Our finding of different MDAs prevalence emphasizes the need for routine serological surveys to monitor the herd immune status. According to available data, sows whose piglets were used in our trial were vaccinated with $\mathrm{C}$-strain at least 5 times in their lifetime and the difference of MDAs prevalence cannot be explained due to the different vaccination status of sows. Considerable variations of MDA status among piglets could be explained by various amounts of colostral uptake by piglets $[12,18,19]$. Application of a subunit vaccine in piglets originating from sows vaccinated with C-strain resulted in a good active immune response in the view of synthesis of specific antibodies. It was established that the MDA deriving from $\mathrm{C}$-strain had no negative influence on subunit vaccination efficacy. These results could be explained by the fact that the subunit vaccine is based on E2 antigen only and it should be considered a killed type [20]. It is well known that inactivated vaccines do not interfere with MDA and thus have no negative influence on the development of active immunity [14]. Therefore, as shown in the presented study, piglets with different MDA status, could be effectively immunized with a subunit vaccine. Any remaining colostral antibodies apparently did not interfere with the response to vaccination. After revaccination of piglets 4 weeks later, a clear anamnestic reaction (booster effect) was observed. A continuous presence of CSFV antibodies was detected until the end of the experimental period.

In the present experimental research, the trend towards short and milder clinical presentations of the disease has been observed. Vaccinated and challenged piglets reacted mainly with an increased body temperature and mild clinical signs. An exception is piglet No. 6, which died on 6 dpi with distinct nervous clinical signs and piglet No. 15, which showed clinical signs of respiratory disease and died on $20 \mathrm{dpi}$. These findings indicate that in piglets vaccinated with a subunit vaccine, after virulent challenge, CSFV can multiply without demonstrating distinct clinical signs. A practical consequence of such a mild presentation of the disease is a delayed diagnosis of the illness due to nonspecific clinical signs which do not raise suspicion for CSF [4]. In succumbed piglets, gross pathology examination indicated petechial hemorrhages in most organ systems and serous membranes that are considered an important characteristics of CSF $[1,16]$. 
In the piglets that survived the challenged infection, gross pathology examination revealed some changes that suggest a successful infection with CSFV.

The aim of the research was also to investigate whether the infected piglets excrete CSFV at levels sufficient to infect susceptible pigs held in close contact. A contact animal was considered contactly infected if it had been positive at least once in the ELISA antigen or $E^{\text {rns }}$ - ELISA $[13,15]$. However, none of the susceptible contact animals manifested neither fever nor clinical signs of CSF and did not seroconverted (D-ELISA), proving that no transmission of the virulent virus to the unvaccinated pigs had occurred. By the control of oropharyngeal and rectal swabs deriving from vaccinated and challenged piglets, the genome of CSFV was detected from 4 to 8 dpi (Table 3), and environmental contamination and horizontal transmission of the virus infection in field conditions, however cannot be excluded. After infection with a virulent CSF strain, large amounts of the virus are excreted in the saliva and smaller quantities in the feces [1]. The oronasal secretions and feces together play an important role in direct and indirect virus transmission [13]. The infection was detected by oropharyngeal swab RT-PCR assay, because ORF swab is considered the first sample type in which the virus can be detected [21]. This seems biologically most appropriate, as the virus replicates first in the tonsil and pharyngeal region, after which it spreads throughout the body [1]. However, stability of viral RNA does not predict the presence of infectious CSFV [21].

In most of the challenged piglets, from 4 to $10 \mathrm{dpi}$, the examined blood samples gave a positive result in antigen ELISA and further RT-PCR testing. The different periods at which viremia in piglets was established may be due to the fact that viremia with a short duration may be missed when samples are taken every two days, or that viremia remains under the detection limit [13]. Based on the obtained results, it may be concluded that RT-PCR investigations represent a diagnostic approach with a clearly enhanced sensitivity as compared to the conventional antigen detection [22]. Detection of viral RNA is possible regardless the course of CSF, even if only mild forms of CSF occur, as well as at the seroconversion phase, in the presence of antibodies [15]. However, though RT-PCR is the method providing the most rapid positive result for $\mathrm{CSFV}$, it is not undoubtedly associated with the presence of infective viral particles in the sample since it detects only the presence of the specific target region of the virus $[15,22]$.

In the tissue samples of challenged pigs, the highest rate of positive results was established in group C. Within group A, negative finding of CSFV antigen in tissue samples in dead piglet No. 6 may be attributed to the per acute disease course [1]. Analysis of the distribution pattern of CSFV antigen revealed the largest number of positive and suspect findings in tissue samples of tonsils, spleen, mandibular lymph nodes and terminal ileum, whereas the smallest number of positive findings was recorded in the kidney tissue. In all examined tissue samples, where the presence of CSFV antigen was detected by ELISA test, the presence of viral RNA was confirmed also by RT-PCR technique. Weesendorp et al. (2010) noted that CSFV is homogenously distributed in 
fresh samples of tonsils, spleen and lymph nodes, thus sampling from these organs enables an accurate and reliable finding. An non homogeneous virus distribution in the kidneys makes these samples less appropriate for diagnostic purposes [23]. Tonsils, nasal and rectal swabs as well as unclotted blood are considered the most appropriate samples for rapid detection of CSF virus in a RT-PCR assay [13,15,22].

By performing the antigen ELISA test and RT-PCR analysis, in piglets vaccinated with the subunit vaccine, after challenge, the replication and excretion of CSFV was detected, though without distinct clinical symptoms of CSF (latent infection). We observed, however, that ORF swab samples of some pigs were RT-PCR positive at several moments, but this was not always the case with blood or tissues samples examined at the moment of euthanasia. Although, CSFV was isolated from the tonsils of most of the vaccinated piglets from group $\mathrm{C}$, these piglets manifested no clinical signs at the end of the experimental period.

In Serbia, regular vaccination of swine with C-strain maintains the country clinically free of the disease. However, since 2010, it has become clear that large outbreaks are possible despite of the vaccination program implemented [11]. Vaccination failure observed in the field is considered to be due to lack of understanding of the herd immune status [8]. The obtained results on the efficacy of the subunit vaccine suggest that the nature of an antigen presented to the immune system can significantly affect the ability of the vaccines to induce protective immunity against CSFV. However, protective efficacy of the E2 subunit vaccines is inferior to that of the MLV [6,7] because two vaccine applications are needed, which in case of emergency vaccination might not be realizable [15]. The use of subunit vaccines could be envisaged when several outbreaks occur at the same time and the use of strict sanitary prophylactic measures alone may not be enough to control the disease $[3,6,7]$. However, due to the ability of vaccination to mask the appearance of clinical signs without preventing infection [20], the vaccinated herds, even those with appropriate serological monitoring programs, represent a greater risk for an undetected spread of the infection than unvaccinated herds, where monitoring can be based on clinical inspection alone [7]. Clinical protection from CSF is not the primary aim in pigs, and might even be contraindicated since it can mask a present infection in an animal that may be a source of a secondary outbreak of the disease [13].

The obtained results suggest no interference effect of passive immunity on protective immunity induced by the subunit vaccine. With regard to CSFV antibodies it was found that all vaccinated piglets responded immunologically in spite of the presence of different MDA status. It was demonstrated that colostral immunity deriving from C-strain CSF had no negative influence on vaccination efficacy with the subunit E2 marker vaccine. In the future, the vaccination plan in Serbia should be based on the knowledge of the herd immune status. Therefore, routine monitoring of the CSFV antibody levels might be used for assessing the effectiveness of a CSF vaccine program in the field. 


\section{Acknowledgements}

This work was supported by Project TR 31084 and TR 31071 of Ministry of Education, Science and Technological Development, Republic of Serbia.

\section{REFERENCES}

1. Moennig V, Floegel-Niesmann G and Greiser-Wilke: Clinical Signs and Epidemiology of Classical Swine Fever: A Review of New Knowledge. Vet J. 2003, 165:11-20.

2. van Oirschot JT: Vaccinology of swine fever: from lab to field.Vet Microbiol 2003, 96:367_ 384.

3. Suradhat S, Damrongwatanapokin S, Thanawongnuwech R: Factors critical for successful vaccination against classical swine fever in endemic areas. Vet Microbiol 2007, 119:1-9.

4. Pérez LJ, de Arce HD, Perer CL, Rosell R, Frías MT, Percedo MI, Tarradas J, Dominguez P, Núñez JI, Ganges L: Positive selection pressure on the B/C domains of the E2-gene of classical swine fever virus in endemic areas under $\mathrm{C}$-strain vaccination. Infection, Genetics and Evolution 2012, 12:1405-1412.

5. Blome S, Grotha I, Moenning V, Greiser-Wilke: Classical swine fever virus in South-Eastern Europe-Retrospective analysis of the disease situation and molecular epidemiology. Vet Microbiol 2010,146: 276-284.

6. Huang YL, Deng MC, Wang FI, Huang CC, Chang CY: The challenges of classical swine fever control: Modified live and E2 subunit vaccines. Virus Research 2014, 179:1-11.

7. Vannier P: Marker vaccines and the impact of their use on diagnosis and prophylactic measures. Rev. Sci. tech. Off. Int. Epir. 2007, 26:351-372.

8. Prodanov J, Došen R, Pušić I, Bugarski D: Passive immunity evaluation in piglets originating from sows vaccinates with China strain of classical swine fever virus. Acta Vet-Beograd 2007, 57(5-6):413-427.

9. Polaček V, Prodanov J, Lazić S, Petrović T, Rašić Z, Aleksić-Kovačević S: Immunohistochemical Detection of B And T Lymphocytes In Mandibular Lymph Nodes Of Experimentally Infected Piglets With Classical Swine Fever Virus. Acta Vet-Beograd, 2007, 57 (2-3):199-208

10. Nedić D, Baltić M, Plavšić B, Tajdić N, Mirilović M, Rajković M: Management and control program for suppression and eradication of classical swine fever in Serbia. Acta VetBeograd 2011, 61(2-3): 295-307.

11. Milićević V, Radojičić S, Valčić AM, Ivović v, Maksimović-Zorić J, Radosavljević: Detection and genotyping of classical swine virus isolates in Serbia. Acta Vet-Beograd 2013, 63 (23):191-200.

12. Lai SS, Chen CS, Huang TH, Ho WC, Wang JT, Wu FM: Immune response of pigs with different levels of colostral antibody to inoculation with LPC-Chinese strain of hog cholera vaccine. J. Chinese Soc. Vet. Sci. 1980, 6:77-81.

13. Dewulf J, Laevens H, Koenen F, Mintiens K, de Kruif A: An E2 sub-unit vaccine does not prevent horizontal or vertical transmission of classical swine fever virus. Vaccine 2002, 20:86-91.

14. Lipowski A, Drexler C, Pejsak Z: Safety and efficacy of classical swine fever subunit vaccine in pregnant sows and their offspring. Vet Microbiol 2000, 77:99-108. 
15. Uttenthal A, Storgaard T, Oleksiewicz MB, Stricker K: Experimental infection with Paderborn isolate of classical swine fever virus in 10-week-old-pigs: determination of viral replication kinetics by quantitative RT-PCR, virus isolation and antigen ELISA. Vet Microbiol 2003, 92:197-212.

16. Polaček V, Prodanov Radulović J, Došen r, Petrović T, Becskei Zsolt, Aleksić-Kovačević $\mathrm{S}$, Expression of E2 (gp 55) glycoprotein of classical swine fever virus in lymphoid tissue and brain of experimentally infected piglets with different immunological status. Acta VetBeograd 2014, 64(2):

17. Katz JB, Ridpath JF, Bolin SR: Presumptive diagnostic differentiation of hog cholera virus from bovine viral diarrhoea and border disease viruses by using a cDNA nestedamplification approach, J Clin Microbiol 1993,31:565-8.

18. Šamanc H, Sladojević Ž, Vujanac I, Prodanović R, Kirovski M, Dudovski P, Kirovski D: Relationship Between Growth Of Nursing Pigs Of Sow colostrum And milk From anterior And Posterior Mammary Glands. Acta Vet-Beograd 2012,63 (5-6): 537-548.

19. Kovačocyová K, Reichel P, Seidel H, Brenesselová M, Kósa B: Influence of beta-glucan and vaccination against Lawsonia intracellularis on selected immune indices in weaned piglets. Acta Vet-Beograd 2014, 64(1): 105-114.

20. Martens M, Rosales C, Morilla A: Evaluation of the use of a subunit classical swine fever marker vaccine under fiels conditions in Mexico. J Swine Health Prod. 2003,11:81-85

21. Weesendorp E, Loeffen W, Stegeman A, de Vos C: Time-dependent infection probability of classical swine fever via excretions and secretions. Preventive Veterinary Medicine 2011, 98:152-164.

22. Dewulf J, Koenen F, Mintiens K, Denis P, Ribbens S, de Kruif A: Analytical performance of several classical swine fever laboratory diagnostic techniques on live animals for detection of infection. Journal of Virological Methods 2004, 119:137-143.

23. Weesendorp E, Willems EM, Loeffen W: The effect of tissue degradation on detection of infectious virus and viral RNA to diagnose classical swine fever virus. Vet Microbiol 2010, 141:275-281.

\section{KLASIČNA KUGA SVINJA: AKTIVNA IMUNIZACIJA PRASADI SUBJEDINIČNOM (E2) VAKCINOM U PRISUSTVU RAZLIČITOG NIVOA KOLOSTRALNOG IMUNITETA}

PRODANOV RADULOVIĆ Jasna, DOŠEN Radoslav, POLAČEK Vladimir, PETROVIĆ Tamaš, STOJANOV Igor, RATAJAC Radomir, VALČIĆ Miroslav

Cilj istraživanja je bio da se utvrdi efikasnost vakcinacije subjedičnom vakcinom protiv infekcije virulentnim virusom KKS kod prasadi poreklom od krmača vakcinisanih Kina sojem. Eksperimenatalna ispitivanja su obavljena na 34 praseta uzrasta 45 dana (13 neimunih i 21 prase poreklom od krmača vakcinisanih Kina sojem). Na osnovu rezultata seroloških ispitivanja prasadi uzrasta 40 dana, formirane su tri eksperimentalne grupe od po sedam prasadi u svakoj. Prasad su vakcinisana subjediničnom vakcinom u uzrastu od 45 dana. Nakon revakcinacije, jedinke su veštački inficirane virulentnim sojem virusa KKS. U cilju kontrole izlučivanja virusa, u svaku eksperimentalnu grupu 
su dodana po dva neimuna praseta. Nakon veštačke infekcije, vršen je klinički pregled prasadi i uzorkovanje krvi od svake životinje u cilju utvrđivanja prisustva antitela protiv virusa KKS i viremije. Kontrola izlučivanja virusa KKS iz organizma vakcinisanih, veštački inficiranih prasadi je vršena tehnikom RT-PCR na uzorcima orofaringealnih i rektalnih briseva. Nakon uginuća ili žrtvovanja, vršen je patomorfološki pregled i uzorkovanje tkiva u cilju utvrđivanje prisustva i distribucije antigena virusa KKS u uzorcima tkiva (ELISA test i RT-PCR). Vakcinacijom prasadi poreklom od krmača vakcinisanih Kina-sojem utvrđen je solidan aktivni imunski odgovor. Nakon veštačke infekcije utvrđeno je izlučivanje virusa ali bez kontaktne infekcije prijemčivih jedinki u kohabitaciji. Rezultati ukazuju da subjedinična vakcina može imati potencijalnu primenu u kontroli KKS u endemski inficiranim područjima. 